\title{
Diversity Management in Organisations Located within the Visegrad Group V4 Countries (The Czech Republic, Poland, Slovakia and Hungary) - State of Implementation and Benefits
}

\author{
Elwira Gross-Gołacka \\ Alcide De Gasperi University of Euroregional Economy \\ Józefów, Poland \\ E-mail: elwira.gross-golacka@wp.pl
}

Received: Jan. 2, 2018 Accepted: Jan. 12, 2018 Published: Feb. 7, 2018

doi:10.5296/bmh.v6i1.12406 URL: http://dx.doi.org/10.5296/bmh.v6i1.12406

\begin{abstract}
The goal of this article is to determine the state of implementation of the concept of diversity management in organisations within countries belonging to the Visegrad Group V4 and gather opinions regarding if and (if so) what benefits result from implementing this concept. For the purposes of the research, the literature on the topic was reviewed and a diagnostic survey was conducted, which was based on a survey questionnaire. Empiric research was conducted in 2016-2017 on a test group of 401 representatives from organisations in the Visegrad Group (Poland, the Czech Republic, Slovakia, Hungary). These were qualitative-quantitative studies. According to the research, the level of implementing diversity management in the organisations examined is low, despite the fact that the representatives saw its benefits and declared their intent to seek more knowledge on this topic. Unequal treatment and discrimination, according to the respondents, occurs most frequently due to age, and at a further stage, due to gender and ethnic origin. The research has shown that according to the opinion of the respondents from the organisations, diversity management carries a multitude of benefits.
\end{abstract}

Keywords: Diversity management, Benefits of diversity, Visegrad Group 


\section{Introduction}

In order for organisations to function effectively, in the current dynamic environment, elasticity is required from them. Today, in a rapidly changing reality, the ability to adapt and to be open to change are instrumental in managing organisations. It should be assumed that the inner and outer surroundings of an organisation elicit the organisation's activity, which ought to reflect the changes taking place on the global (or local) and competition market. It therefore seems that the success and competitiveness of an organisation depends on its ability to implement and accept diversity and realise what benefits stem from it. With an assumption stated as such, in an environment of changes in the modern world, an urgent need arises for a new viewpoint on the most important resource that an organisation possesses, which are people and human capital, which is characterised by competences, subjectivity and responsibility. Today, success is not based on meticulously organised process flows, but on the ability to adapt, decision-making speed, utilising intuition and accepting risk (Skrzypek, 2009, pp. 234-243). Interesting observations come from the Economist Intelligence Unit (EIU) Report on the topic of diversity in business, presenting the research entitled Value based diversity. The challenges and strengths of many (Value based diversity, 2014), which had been conducted in 2013 among 228 HR directors from the entire globe. $80 \%$ of them had declared that in the following years diversity will be one of the key competitive advantages on the labour market, but also the biggest challenge of over a decade, which organisations will have to face. Companies that recruit diverse employees are able to enter new markets more easily, are able to tailor their products and services to their customers' expectations more efficiently, but also build long-term relationships with clients more effectively.

As a consequence of these deliberations, the main aim of this article has developed, namely to identify the state of implementation of the concept of diversity management in organisations within countries of the Visegrad Group V4, as well as determining whether this concept presents benefits to organisations, and if so, then what are they. While conducting the research, the literature on the topic was reviewed and a diagnostic survey was conducted, which was based on the technique of a survey questionnaire. This allowed to formulate conclusions, including postulative ones, as well as recommendations regarding the necessary changes in management, directed at managing diversity.

\section{Diversity Management-Theoretical Aspects}

The term "diversity management" has been used for the first time in the United States in the 80 s of the 20th century, and only in the 90s of the 20th century, the concept has found its reflection in the activities undertaken by organisations. It has to be noted that the concept has developed based on historical developments, but it is also strongly rooted in practice.

Diversity management is a wide and complex term, and therefore it seems that it is difficult to set a single standard or system encompassing all aspects associated with the issue. Authors in multiple publications define the field and its components in different ways. An overview of them allows one to observe that diversity management is an interdisciplinary category, which utilises several perspectives, namely economics, social and biological ones. 
Classically, (see e.g., Mor Barak, 2011, pp. 136-145; Thomas, 1999; Thomas, 1991; Loden \& Rosener, 1991) diversity has been defined as a mosaic of characteristics brought to the organisation by employees; characteristics such as gender, age, race, ethnicity, religion, family conditions or physical abilities. Diversity among employees can also be concerned with the diversity of functions in a given organisation. It also includes lifestyle, sexual preferences, origin, work experience at an organisation, the status of being let go or employed. Diversity, in its broad definition, can relate to any perceived difference and similarity between people, both observable and otherwise (the effect will be a wide and universal approach). Özbilgin \& Tatli (2008) defines diversity management as a management philosophy, meaning that diversity in organisations is recognised and valued, and that the goal is to increase the performance of the organisation. Egan \& Bendick (2008, pp. 387-393) define diversity management as a systematic and planned creation of programmes and procedures, aimed at improving the interaction between different (based on ethnic origin, gender and culture) employees in order to make diversity a source of creativity, complementarity and higher effectiveness of an organisation (...)". Generally, diversity management regards utilising all available talents in an organisation, without referring to ethnocentrism and stereotypes. It regards to a group of employees: conducting policy on behalf of diversity, while contributing to an increase of innovativeness and creative activities, reducing any lacks of human resources with specified abilities and improving the quality of service for clients. It approach through strategic management oriented towards adapting the organisation to its environment. Diversity management is made up by all activities of an organisation, which are aimed at including optimal utilisation of diversity in the workplace.

While reviewing the selected definitions of diversity management and for the purposes of the empirical evidence analysis presented in this article, the author's aim was to delineate a complex way of understanding them. Diversity is understood as a collection of characteristics, including all characteristics differentiating one person from another (in terms of employees) and their similarities. Nonetheless, the concept of diversity management regards:

- utilising all available talents in an organisation, without referring to ethnocentrism and stereotypes,

- with regards to a group of employees: conducting policy on behalf of diversity, while contributing to an increase of innovativeness and creative activities, reducing any lacks of human resources with specified abilities and improving the quality of service for clients,

- with regards to the company: further fulfilment of needs of clients, increasing the market share, both in terms of individual clients and employees and stakeholders,

- approach through strategic management oriented towards adapting the organisation to its environment.

\section{Benefits of Implementing the Diversity Management Concept}

A review of the literature on the topic and experience of practitioners allows one to observe that the implementation of the concept of diversity management ensures the ability to improve the operational results of an organisation the short and medium -term perspective as well as 
strategic assets of the company in the long-run. Investments made towards managing diversity contribute to creating and reinforcing human and organisational capital, which today is an important element influencing effectiveness. It therefore seems that diversity in an organisation carries many benefits, including those in a macroeconomic perspective-which contributes to increasing efficiency, increasing innovativeness and creative activities, or gaining new markets and maintaining current ones. Whereas the improvement of goods and services for the benefit of the clients, attracts talents from the widest possible group of potential employees, reduces any lacks of human resources and limits fluctuations of employees - these are all benefits from a micro-economic perspective (Sonnenschein, 1997, pp. 3-4).

Fundamentally, in the topic literature and in the presented points of view of practitioners, it is pointed out that managing diversity contributes to benefits, which can be assessed from a perspective of the time needed to attain them (Table 1).

Table 1. Benefits stemming from implementing the concept of diversity management based on the time needed to attain them

\begin{tabular}{|c|c|}
\hline & \\
\hline Shor & $m$ \\
\hline $\begin{array}{l}\text { - Influence on managing talents } \\
\text { - Increasing innovativeness and creativity } \\
\text { - Forming a culture based on tolerance } \\
\text { - Reinforcing the image and reliability of the } \\
\text { company externally, among clients and business } \\
\text { partners } \\
\text { - Good reputation among employees } \\
\text { - Ensuring loyalty from employees, clients and } \\
\text { - } \text { business partners } \\
\text { - } \text { the inside of an organisation } \\
\text { and experience exchange easier } \\
\text { - Increasing the flexibility of the organisation } \\
\text { Breaking through known schemes and routine } \\
\text { activity }\end{array}$ & $\begin{array}{l}\text { - Reaching new groups of candidates on the labour } \\
\text { - Inarket } \\
\text { talented employees } \\
\text { - Conquering new markets } \\
\text { - Development of new products and services } \\
\text { - Better response to the needs of (new) diversified } \\
\text { customers } \\
\text { - The ability to reach a larger number of recipients of } \\
\text { - products and services } \\
\text { - Better response to the needs of diversified customers } \\
\text { - Rowering the costs associated with fluctuations of } \\
\text { employees and their absence }\end{array}$ \\
\hline
\end{tabular}

Source: author's own research, based on Gross-Gołacka, E. (2018). Zarzq̨dzanie różnorodnościa. W kierunku zróżnicowanych zasobów ludzkich w organizacji. Warszawa: Difin.

Diversity within human resources can potentially lead to the creation of conflicts, however if well-managed, it can result in a synergy effect, as the results of working together are improved, even if compared to the sum of individual activities, which has been proven in the 80 s by an American researcher Belbin (2009). The ability to manage teams comprising of diversified 
employees in terms of their age, race and gender, is beginning to amount to common practice in global firms. As pointed out by Pocztowski (2015, p. 28), a crucial role in the context of diversity among human resources is played by building a leadership sensitive to cultural differences (and not only), one that is able to focus employees coming from different cultural circles and having different preferences in terms of leadership behaviour.

The benefits outlined above can be measured quantitively and their relationship with investments in diversity management policy can be established. However, this relationship only remains partial. At the same time, there is a lack of transparency with regards to the employed indicators used in research, as both in managing human resources and in managing diversity, it is difficult to indicate a direct and singular dependency of the activities on the financial profit of the firm (Monks, 2007; Kirton \& Greene, 2005; Managing diversity. Linking theory and practice to business performance, 2005; Diversity Matters, 2014).

According to the author, it seems that the character and reach of the undertaken activities in organisations can depend on the size, scope and character the company's activities. Organisations employ diversity management policies for more than one of the aforementioned reasons, which interact with each other and are considered collectively and reflect strong impulses to meaningful internal changes within an organisation. But the relative importance of each of these reasons has changed also depending on the organisation and its characteristics (Methods and Indicators to Measure the Cost-Effectiveness of Diversity Policies in Enterprises Final Report, 2003, pp. 20-40; The costs and benefits of diversity, 2003, pp. 10-12).

\section{Methodology and Data}

The main research goal was to identify the state of implementation of the concept of diversity management in organisations, as well as establishing whether this concept delivers any benefits, and if so, what are they, based on the opinions of representatives of enterprises located in countries, which are members of the Visegrad Group V4 (Poland, the Czech Republic, Slovakia, Hungary). The secondary goal was getting insight into the social characteristics, which can be contributing factors to unequal treatment and discrimination in an organisation, according to the representatives of the organisation. The empirical exploration conducted aimed at finding the answers to the specified research problems, which took the form of the following questions:

1). Have the representatives of organisations located in countries belonging to the Visegrad Group V4 had contact with the concept of diversity management?

2). Is there a perceived need for diversity management in organisations located in countries belonging to the Visegrad Group V4?

3). In relation to what social characteristics, according to the representatives of organisations located in countries belonging to the Visegrad Group V4, does unequal treatment and discrimination occur?

4). What benefits, according to the representatives of organisations located in countries 


\section{Al Macrothink}

Business and Management Horizons

ISSN 2326-0297

2018, Vol. 6, No. 1

belonging to the Visegrad Group V4, stem from implementing the concept of diversity management?

\subsection{Measurements}

The main subject of the research was thus the level of implementation of diversity management and the resulting benefits, whereas the subject were representatives of organisations located in countries belonging to the Visegrad Group V4 (Poland, the Czech Republic, Slovakia, Hungary). The quantitative-qualitative research was conducted in 2016-2017 in frames of the international project entitled „Diversity management in the V4 countries as an answer for demographic changes", which was supported by the International Visegrad Fund. For the purposes of the research a method of a diagnostic computer-assisted personal interviewing (CAPI) technique was chosen, and the tool used was an electronic questionnaire as the means of asking the questions and obtaining answers. The questionnaire contained closed questions (multi-aspect ones), as well as open questions and was comprised of two parts, with the following titles:

- The Term: Diversity Management (5 questions),

- Workforce Changes (15 questions).

The questionnaire was constructed in such a manner, as to allow the respondents to choose from the proposed options or indicate their own answers. Questionnaire was conducted in its original English format in Hungary. In the other counties the questionnaire was conducted in national language.

\subsection{Data Analysis}

In this research, the researcher use the Statistical Package for Social Science (SPSS) Version 21 to analyse the data collected from respondents. All of the items and variables in the questionnaire were coded before it was distributed to the respondents. Statistical methods were used in data analysis.

In this research which was of an anonymous character, 401 respondents took part willingly, who were employees (management representatives) or owners of organisations from Poland, the Czech Republic, Slovakia and Hungary.

\subsubsection{Respondent Profile}


Table 2. Respondent profile

\begin{tabular}{|c|c|c|c|}
\hline \multicolumn{2}{|c|}{ Respondent charactersitics } & Frequency & Precentage $(\%)$ \\
\hline \multirow{4}{*}{ Type of organization } & Private enterprises & 272 & 67.80 \\
\hline & State-owned enterprises & 48 & 12.00 \\
\hline & NGO & 40 & 10.00 \\
\hline & Other & 41 & 10.20 \\
\hline \multirow{4}{*}{ Number of employees } & under 10 employees & 71 & 17.70 \\
\hline & 10-49 employees & 128 & 31.90 \\
\hline & 50-249 employees & 110 & 27.40 \\
\hline & more than 249 & 92 & 22.90 \\
\hline \multirow{6}{*}{ Position } & President/vice president & 15 & 3.70 \\
\hline & Owner/co-owner & 99 & 24.70 \\
\hline & Director/Head of HR & 34 & 8.50 \\
\hline & Director/Head of PR & 47 & 11.70 \\
\hline & Specialist of HR & 93 & 23.20 \\
\hline & Other position & 113 & 28.20 \\
\hline \multirow{5}{*}{ Age } & below 30 years & 63 & 15.70 \\
\hline & 30-39 years & 92 & 22.90 \\
\hline & 40-49 years & 131 & 32.70 \\
\hline & $50-59$ years & 82 & 20.40 \\
\hline & 60 years + & 33 & 8.20 \\
\hline \multirow{2}{*}{ Sex } & Female & 223 & 55,60 \\
\hline & Male & 178 & 44.40 \\
\hline
\end{tabular}

The research sample consisted of $55.60 \%$ of women and $44.40 \%$ men. In terms of age, the largest group of respondents were people of 40-49 years of age $(32.70 \%)$, followed by the $30-39$ age group $(22.90 \%)$ and below 30 years of age (15.70\%). Essentially, people over 40 years of age constituted almost $62 \%$ of all respondents.

The majority of respondents were owners/co-owners of enterprises $(24.70 \%)$ and representatives of the group "other positions" (28.20\%). 17\% of the respondents represented the positions of HR specialists and $11 \%$ were personnel directors. People representing the position of president/vice-president were in the minority at $3.70 \%$, whereas $11.70 \%$ were PR directors.

The majority of the companies that partook in the research were private enterprises $(67.80 \%)$, $12 \%$ were state-owned enterprises, and only $10 \%$ were NGOs. Taking into account the size of the organisations that took part in the research, small organisations employing 1-49 people constituted $49.60 \%$ (of which: those that employ less than 10 employees- $17.70 \%$ and $10-49$ employees 31.90\%), medium (with 50-249 employees-27,40\%) and large (over 250 employees, $22.90 \%$ ).

Data analysis of the characteristics of the research sample allows to formulate the conclusion that the group of respondents was very diversified, taking into account each diversity criterion.

\section{Research Results}

The research highlights that knowledge pertaining to diversity management among companies 
located in states belonging to the Visegrad Group V4 is not widely-spread. While $40 \%$ of respondents from the studied countries heard about the concept, in contrast, another $40 \%$ of the respondents never heard about it. Also, only $14 \%$ of the of the companies participating in the study saw the implementation of the concept in practice.

Table 3. Have you ever heard the concept of Diversity management? (\%)

\begin{tabular}{|l|l|l|l|l|l|}
\hline Answer & Hungary & the Czech Republic & Poland & Slovakia & V4 countries \\
\hline Yes. I have heard something about it & 27.00 & 39.60 & 63.00 & 42.00 & 42.90 \\
\hline Yes, I met it in practice & 17.00 & 23.76 & 8.00 & 6.00 & 13.69 \\
\hline No, I have never heard with it & 56.00 & 36.63 & 29.00 & 52.00 & 43.41 \\
\hline
\end{tabular}

From the perspective of the respective states, the most respondents (63\%), who heard about the concept were located in Poland, whereas the least heard about it in Hungary (29\%). In the study, the participants were asked whether in their opinion utilising and implementing the concept of diversity management is important for the company.

Table 4. Do you think it is important for the company to have a Diversity management? (\%)

\begin{tabular}{|l|l|l|l|l|l|}
\hline Answer & Hungary & the Czech Republic & Poland & Slovakia & V4 countries \\
\hline Yes & 76.00 & 36.63 & 78.00 & 52.00 & 60.66 \\
\hline No & 14.00 & 10.89 & 8.00 & 16.00 & 12.22 \\
\hline I don't know & 10.00 & 52.48 & 14.00 & 32.00 & 27.12 \\
\hline
\end{tabular}

The responses allow one to make the observation that $60.7 \%$ respondents see the concept as being important for companies; this mainly pertains to companies from Poland (78\%) and Hungary (76\%). However, only $12 \%$ of the respondents believe that implementing diversity management is not important for the activity of the company, whereas $27 \%$ did not have any knowledge on the subject.

This low awareness of the concept of diversity management in Visegrad Group V4 countries is also present when it comes to the progress level of activity in this area at organisations (table 5 refers). 
Table 5. Does your company have a Diversity management strategy? (\%)

\begin{tabular}{|l|l|l|l|l|l|}
\hline Activity & Hungary & $\begin{array}{l}\text { the Czech } \\
\text { Republic }\end{array}$ & Poland & Slovakia & $\begin{array}{l}\text { V4 } \\
\text { countries }\end{array}$ \\
\hline Yes, we have as a separate document & 6.00 & 8.91 & 6.00 & 2.00 & 5.73 \\
\hline $\begin{array}{l}\text { Yes, elements of the Diversity management } \\
\text { strategy are located in other strategic } \\
\text { documents of the company }\end{array}$ & 4.00 & 6.93 & 8.00 & 7.00 & 6.48 \\
\hline $\begin{array}{l}\text { Yes, elements of the Diversity management } \\
\text { strategy are elements of a code of ethics }\end{array}$ & 33.00 & 25.74 & 26.00 & 10.00 & 23.69 \\
\hline We do not have, we plan to develop a strategy & 12.00 & 23.76 & 17.00 & 26.00 & 19.69 \\
\hline $\begin{array}{l}\text { We do not have, we are not planning to develop } \\
\text { such a strategy }\end{array}$ & 45.00 & 34.65 & 43.00 & 55.00 & 44.41 \\
\hline
\end{tabular}

Only about $12.2 \%$ companies have dedicated documents on diversity management $(5.7 \%$ have a separate document/strategy; $6.5 \%$ companies have diversity management elements in different strategic documents). This state of business is observable in all of the countries in question. In the other $23.7 \%$ of organisations, elements of the concept of diversity management are elements of the code of ethics (except companies from Slovakia-10\%). Over half $(64.1 \%)$ of the organisations do not have a diversity management strategy; of which $1 / 5$ of the companies participating in the study plan to develop such a strategy, whereas the remaining $44.4 \%$ of organisations are not planning on developing such a strategy. The most companies planning to develop a diversity management strategy are located in the Czech Republic (26\%) and Slovakia (24\%), and the least in Hungary (12\%). On the other hand, the most companies, which are not planning to develop a diversity management strategy have been identified in Slovakia (55\%) and Hungary (45\%).

An important aspect associated with introducing pro-diversity policy at organisations is the issue of unequal treatment and workplace discrimination. Respondents in the study were asked about delineating which social groups are most prone to unequal treatment and workplace discrimination (table 6).

Table 6. Which social groups are most prone to unequal treatment and workplace discrimination? (\%)

\begin{tabular}{|l|l|l|l|l|l|}
\hline Type & Hungary & the Czech Republic & Poland & Slovakia & V4 countries \\
\hline Age & 35,00 & 61,39 & 29,00 & 36,00 & 42,13 \\
\hline Gender & 33,00 & 43,56 & 17,00 & 28,00 & 29,52 \\
\hline Ethnic origin & 37,00 & 16,83 & 21,00 & 42,00 & 26,61 \\
\hline Religion/ belief & 14,00 & 5,94 & 4,00 & 11,00 & 6,98 \\
\hline Disability & 28,00 & 26,73 & 7,00 & 18,00 & 17,24 \\
\hline Educational & 56,00 & 36,63 & 5,00 & 46,00 & 29,21 \\
\hline Sexual orientation & 25,00 & 6,93 & 17,00 & 6,00 & 9,98 \\
\hline
\end{tabular}


It turned out that according to the respondents, it is the age of an employee which is the most common reason for this negative phenomenon. $40 \%$ of the respondents believed this to be true. In this inglorious ranking, what followed the criterion of age, was education, followed by gender $(30 \%)$ and ethnic origin $(29 \%)$. This distribution of responses varies among members of the Visegrad Group. The most common characteristic that could contribute to unequal treatment and workplace discrimination is age - in the Czech Republic (61.39\%) and Poland (29\%), whereas in Hungary (56\%) and Slovakia (42\%) - education. The second most common characteristic for Hungary (37\%), Poland (21\%) and Slovakia (42\%) was ethnic origin, and for the Czech Republic it was gender (43.6\%).

From the study, it was possible to determine what benefits stem from diversity management at organisations. It was determined that the surveyed companies saw clear benefits of implementing this concept, but they can be very different (table 7). The respondents identified what benefits can be obtained from implementing the concept of diversity management through assigning between 1-5 points to every answer, where 1 meant that diversity management contributes the least, while 5 meant that it brings the most benefits for the company.

Table 7. Benefits of the diversity management (\%)

\begin{tabular}{|l|l|l|l|l|l|l|}
\hline Benefits of the Diversity Management & $\mathbf{1}$ & $\mathbf{2}$ & $\mathbf{3}$ & $\mathbf{4}$ & $\mathbf{5}$ \\
\hline "1" means that managing diversity contributes the least, and "5" & in the highest degree & \multicolumn{2}{l|}{} \\
\hline Improving the image of the company & 13.20 & 8.40 & 30.50 & 21.90 & 20.60 \\
\hline Better motivation and performance of employees & 10.70 & 10.80 & 19.50 & 40.10 & 13.30 \\
\hline Better satisfaction of employees & 9.00 & 10.80 & 24.60 & 22.20 & 26.70 \\
\hline Increasing company profit & 11.70 & 12.40 & 29.10 & 28.90 & 11.80 \\
\hline Access to new markets, retaining new customers & 11.20 & 10.40 & 21.40 & 31.90 & 18.60 \\
\hline Getting the best personnel & 8.20 & 8.90 & 20.00 & 36.70 & 19.00 \\
\hline Retaining the best talents & 8.70 & 8.30 & 19.70 & 30.70 & 25.50 \\
\hline Increasing creativity and innovation by building diverse teams & 7.50 & 9.50 & 17.60 & 25.30 & 31.00 \\
\hline To avoid any risk of discrimination in the company & 8.20 & 10.50 & 25.00 & 28.3 & 21.4 \\
\hline Increasing client loyalty & 11.90 & 14.70 & 21.10 & 23.60 & 20.20 \\
\hline Reduced costs & 18.40 & 16.80 & 24.90 & 19.40 & 14.90 \\
\hline No benefits & 53.60 & 8.40 & 16.70 & 7.40 & 9.90 \\
\hline
\end{tabular}

The benefits of implementing the concept of diversity management at organisations, which have received the most positive indicators from the organisations in question (4 and 5 points), include: maintaining the biggest talents at a company/decreasing the number of employees leaving (56.2\%), increasing creativity and innovativeness through building diversified teams $(56.3 \%)$, obtaining the best employees for the company $(55.7 \%)$ and better motivation and performance of employees/limiting absences (53.4\%). The aforementioned benefits clearly show that implementing the concept of diversity management can have an important impact on obtaining and retaining best employees at an organisation as well as increasing their motivation, creativity and innovativeness.

A slightly smaller group of respondents saw the benefits of: accessing new markets and obtaining new clients $(50.5 \%)$, limiting risk associated with discrimination at an 
organisation/avoiding lawsuit (49.7\%) or better satisfaction among employees (48.9\%). Slightly fewer positive assessments were given to the issue of increasing customers' loyalty/retaining current clients $(43.8 \%)$, improving the image and reputation of the company (42.6\%) and increasing the company's profits (40.8\%), whereas the least points were given to "reducing costs (obtaining, employing, training and replacing employees)" (34.3\%). 17,8\% respondents confirmed that managing diversity does not deliver any benefits. On the other hand, $62 \%$ of the participants do not agree with the statement that diversity management delivers very limited and few benefits. Furthermore, 35.2\% of respondents did not confirm that diversity management can contribute to reducing costs (of obtaining, employing, training and replacing employees) and $26,6 \%$ believed it could not translate into increased customer's loyalty/maintaining current clients. Finally, it was established that about $30 \%$ of respondents believe that diversity management - to a medium extent - contributes to improving the image and reputation of a company and increasing the firm's profits.

The opinions of companies from V4 countries are often similar to the results of studies by other researchers. It is clear that the issues of diversity management and utilisation are not well-known in the V4 countries. Some people never had contact with diversity management. But it is also estimated that diversity management can bring multiple benefits for companies taking advantage of diversity in its activity and they are able to define it. They mention as being the most important: retaining the best talents and increasing creativity and innovativeness by building diverse teams or better motivation, satisfaction and performance of employees. Respondents from V4 countries are also aware of possibility of discrimination, which can result from diversity. The most wide-spread discrimination by them is discrimination based on age. Other sources of discrimination are education and gender.

\section{Conclusion}

The goal of this article, namely identifying the state of implementation of the concept of diversity management in organisations functioning in countries belonging to the Visegrad Group V4, as well as establishing whether and what benefits it delivers, based on the opinions of representatives of organisation located in Poland, the Czech Republic, Slovakia and Hungary, has been realised successfully. Moreover, it has been established which social characteristics could lead to discrimination and unequal treatment in the workplace and on the labour market. The state of implementation of the concept of diversity management in Visegrad Group V4 countries is low. According to the participants of the survey, activity in this area brings an array of different benefits for organisations.

It is necessary to continue efforts in the area in question. Most likely, the state of knowledge in organisations functioning in V4 countries, with regards to the concept of diversity management is low. Spreading the notion of diversified human resources and what tendencies govern this area, is therefore necessary. It requires multi-aspect actives in this area. Firstly, wide-scope training and education is required for all employees in the organisation (including the management level), which is aimed at eliminating stereotypes and prejudice as well as all indicators of discrimination and unequal treatment at the workplace and also promoting the concept of diversity management itself. Secondly, directing attention towards the benefits, 
which can be gained by an organisation from obtaining, retaining and utilising diversified human resources at an organisation with the aim of professionally constricting a line of reasoning for the undertaken actions. A well-defined justification (business/social/ethical) is an important element for implementing diversity management at an organisation. There are several motivations for implementing the strategy and practices supporting diversity. Beginning with issues of ethical and social justice, legislative requirements, binding market regulations, and ending with strictly economic benefits for an organisation. Generally, the justification for the undertaken activity is the main driver of change. According to the author, it seems that in order to get the attention of the leaders and managers and obtain actual benefits from implementing diversity at an organisation and managing it, one has to provide a comprehensive business justification, which should be understandable by all participants of the process. These issues are closely associated with both the vision and mission statements, but also leadership philosophy. With regards to the former, several research priorities emerge, which pertain to diversity management in an organisation, measuring it and its relationship with obtainable benefits at organisations, aimed at building an increasingly more fluent justification for the actions undertaken in this area. Another research direction for science, as well as for practitioners, is building awareness of the concept of diversity management and its role in managing organisations.

\section{References}

Assessing Diversity Impact in Business. By the European Union Platform of Diversity Charters. (2013). European Union. [Online]. Available: http://ec.europa.eu/justice/events/hle-2013/files/assessing_diversity2013_en.pdf

Begeç, S. (2013). Effective diversity management initiatives. International Review of Management and Marketing, 3(2), 63-74.

Belbin, M. (2009). Zespoły zarządzające, sekrety ich sukcesów i porażek. Kraków: Wolters Kluwer business.

Charles, J. (2003). Diversity Management an Exploratory Assessment of Minority Group Representation in the State Government. Public Personnel Management, 32(4), 561-577. https://doi.org/10.1177/009102600303200407

Diversity Matters. (2014). McKinsey \& Company.

Egan, M., \& Bendick, M. (2008). Combining multicultural and diversity into one course on cultural competence. Academy of Management Learning and Education, 7(3), 387-393. https://doi.org/10.5465/amle.2008.34251675

Friday, E., \& Friday, S. (2003). Managing diversity using a strategic planned change Approach. Journal of Managament Development, 22, 863-888. https://doi.org/10.1108/02621710310505467

Gilbert, J., Stead, A., Bette, A., \& Ivancevich, J. (1999). Diversity management; a new organizational paradigm. Journal of Business Ethics, 21(1), 61-76. https://doi.org/10.1023/a:1005907602028 
Griffin, R. (2005). Podstawy zarządzania organizacjami. Warszawa: PWN.

Gross-Gołacka, E. (2016). Rola koncepcji zarządzanie różnorodnością w doskonaleniu organizacji, Problemy Jakości nr 4, 28-34. https://doi.org/10.15199/47.2016.4.5

Gross-Gołacka, E. (2018). Zarządzanie różnorodnością. W kierunku zróżnicowanych zasobów ludzkich w organizacji. Warszawa: Difin.

Gross-Gołacka, E. (2008). Jak pozyskać i zatrzymać pracownika w organizacji. Warszawa: UNDP.

Jamka, B. (2011). Czynnik ludzki we współczesnym przedsiębiorstwie zasób czy kapitat?. Warszawa: Wolters Kluwer business.

Kandola, R., \& Fullerton, J. (1998). Diversity in Action. Managing the Mosaic. London: Institute of Personnel and Development.

Kirton, G., \& Greene, A. M. (2005). The Dynamics of Managing Diversity. A Critical Approach. Oxford: Elsevier Butterworth-Heinemann.

Klarsfeld, A., Ng, E., \& Tatli, A. (2012). Social regulation and diversity management: A comparative study of France, Canada and the UK. European Journal of Industrial Relations, 18(4), 309-327. https://doi.org/10.1177/0959680112461091

Konopacka, A. (2010). Latwiejsza i efektywniejsza wspótpraca w zespole. Różni znaczy skuteczniejsi?, Zarządanie przez różnorodność, korzyści dla firm i pracowników. Warszawa: Wyd. Stowarzyszenie na rzecz Zrównoważonego Rozwoju.

Kossek, E. E., Lobel, S. A., \& Brown, J. (2006). Human Resource Strategies to Manage Workforce Diversity Examining “The Business Case”. In. A. M. Konrad, P. Prasad, \& J. K. Pringle (Eds.), Handbook of workplace diversity (pp. 54-75). San Francisco: Sage Thousand Oak. https://doi.org/10.4135/9781848608092.n3

Kupczyk, T. (2009). Kobiety w zarządzaniu i czynniki ich sukcesów. Wrocław: Wyższa Szkoła Handlowa we Wrocławiu.

Managing diversity. Linking theory and practice to business performance. (2005). London: Chartered Institute of Personnel and Development.

Managing Diversity. Measuring success. (2006). London: Charted Institute of Personnel Development.

Methods and Indicators to Measure the Cost-Effectiveness of Diversity Policies in Enterprises Final Report. (2003). London: Centre for Strategy \& Evaluation Services.

Monks, K. (2007). The business impact of equality and diversity. Dublin: The international evidence. Equality Research Series The Equality Authority I National Centre for Partnership and Performance.

Mor Barak, M. E. (2011). Managing Diversity, Toward a Globally Inclusive Workplace. Thousand Oaks. CA: Sage Publications. 
Özbilgin, M. F., \& Tatli, A. (2008). Global Diversity Management: an evidence-based approach. Basingstoke: Palgrave Macmillan.

Özbilgin, M. F., \& Tatli, A. (2011). Mapping out the field of equality and diversity: rise of individualism and voluntarism. Human Relations, 64(9), 1229-1253. https://doi.org/10.1177/0018726711413620

Pocztowski, A. (2002). Międzynarodowe zarządzanie zasobami ludzkimi. Kraków: Oficyna Ekonomiczna.

Pocztowski, A. (2015). Zarzadzanie zasobami ludzkimi na rynkach międzynarodowych. Warszawa: Wolters Kluwer business.

Rawłuszko, M. (2008). Zarządzanie różnorodnością a przeciwdziałanie dyskryminacji. In Podręcznik trenerski. Zarządzanie firma równych szans (pp. 21-22). Warszawa: Program Narodów Zjednoczonych ds. Rozwoju.

Różnorodność $w$ firmach-dobre praktyki $w$ miejscu pracy. Podstawowe prawa $i$ przeciwdziałanie dyskryminacji. (2005). Bruksela: Komisja Europejska.

Skrzypek, E. (2009). Kapitał ludzki i jego wplyw na jakość. Kraków: Outsourcing.

Sonnenschein, W. (1997). The Diversity Toolkit. How You Can Build and Benefit from a Diverse Workforce. New York: McGraw-Hill Companies.

Sznajder, A. (2013). Przewodnik po zarządzaniu różnorodnością. Warszawa: PKPP Lewiatan.

The costs and benefits of diversity. A Study on Methods and Indicators to Measure the Cost-Effectiveness of Diversity Policies in Enterprises of Diversity Policies in Enterprises. (2003). Bruksela: European Commission.

Thomas, R. R. Jr. (1991). Beyond race and gender. Unleashing the power of your total work force by managing diversity. New York: Amacom.

Thomas, R. R. Jr. (1999). Building a House for Diversity. New York: Amacom.

Urbaniak, B. (2014). Zarządzanie różnorodnością zasobów ludzkich w organizacji. Zarzadzanie Zasobami Ludzkimi, 3-4(98-99), 63-79.

Value based diversity. The challenges and strengths of many. (2014). The Economist Intelligence Unit Limited. [Online] Avaiable: http://tammyerickson.com/images/uploads/EIU_SuccessFactors_Proof_06.pdf

Walczak, W. (2011). Zarządzanie różnorodnością jako podstawa budowania potencjału kapitału ludzkiego organizacji. E-mentor, 3(40). [Online] Available: http://www.e-mentor.edu.pl/artykul/index/numer/40/id/840

Wiktorska-Święcka, A. (2013). Płeć kulturowa a współpraca kobiet i mężczyzn w zarządzaniu z perspektywy koncepcji zarządzania różnorodnością. In T. Kupczyk (Eds.), Kobiety i mężczyźni w zarządzaniu - korzyści, problemy, dobre praktyki, propozycja zmian (pp. 207-218). Wrocław: Wyższa Szkoła Handlowa we Wrocławiu. 
Yang, Y. (2005). Developing cultural diversity advantage: the impact of diversity management structures. Academy of Management Annual Meeting Proceedings, H1-H6. https://doi.org/10.5465/ambpp.2005.18778669

\section{Copyright Disclaimer}

Copyright for this article is retained by the author(s), with first publication rights granted to the journal.

This is an open-access article distributed under the terms and conditions of the Creative Commons Attribution license (http://creativecommons.org/licenses/by/3.0/). 